\title{
Enhanced Adsorption and Mass Transfer of Hierarchically Porous Zr-MOF Nanoarchitectures towards Toxic Chemical Removal
}

Xinbo Wang, ${ }^{\dagger}$ Ruyue Su, ${ }^{\dagger}$ Yue Zhao, ${ }^{\dagger}$ Wenhan Guo, ${ }^{+}$Song Gao, ${ }^{+}$Kai Li ${ }^{\dagger}$ Guojie Liang, ${ }^{\dagger}$

Zhiqiang Luan, ${ }^{\dagger}$ Li Li, ${ }^{*}+{ }^{\dagger}$ Hailing $X i,{ }^{*}, \dagger$ Ruqiang Zou ${ }^{*},+$

†State Key Laboratory of NBC Protection for Civilian, Research Institute of Chemical

Defense, Beijing 100191, China

*Beijing Key Laboratory for Theory and Technology of Advanced Battery Materials,

School of Materials Science and Engineering and Institute of Clean Energy, Peking

University, Beijing 100871, China

*To whom correspondence should be addressed. E-mail: lily97@buaa.edu.cn.

xihailing@sklnbcpc.cn.rzou@pku.edu.cn.

Number of Tables: 15; Number of Figures: 18. 


\section{S1. Experimental apparatus and parameters.}

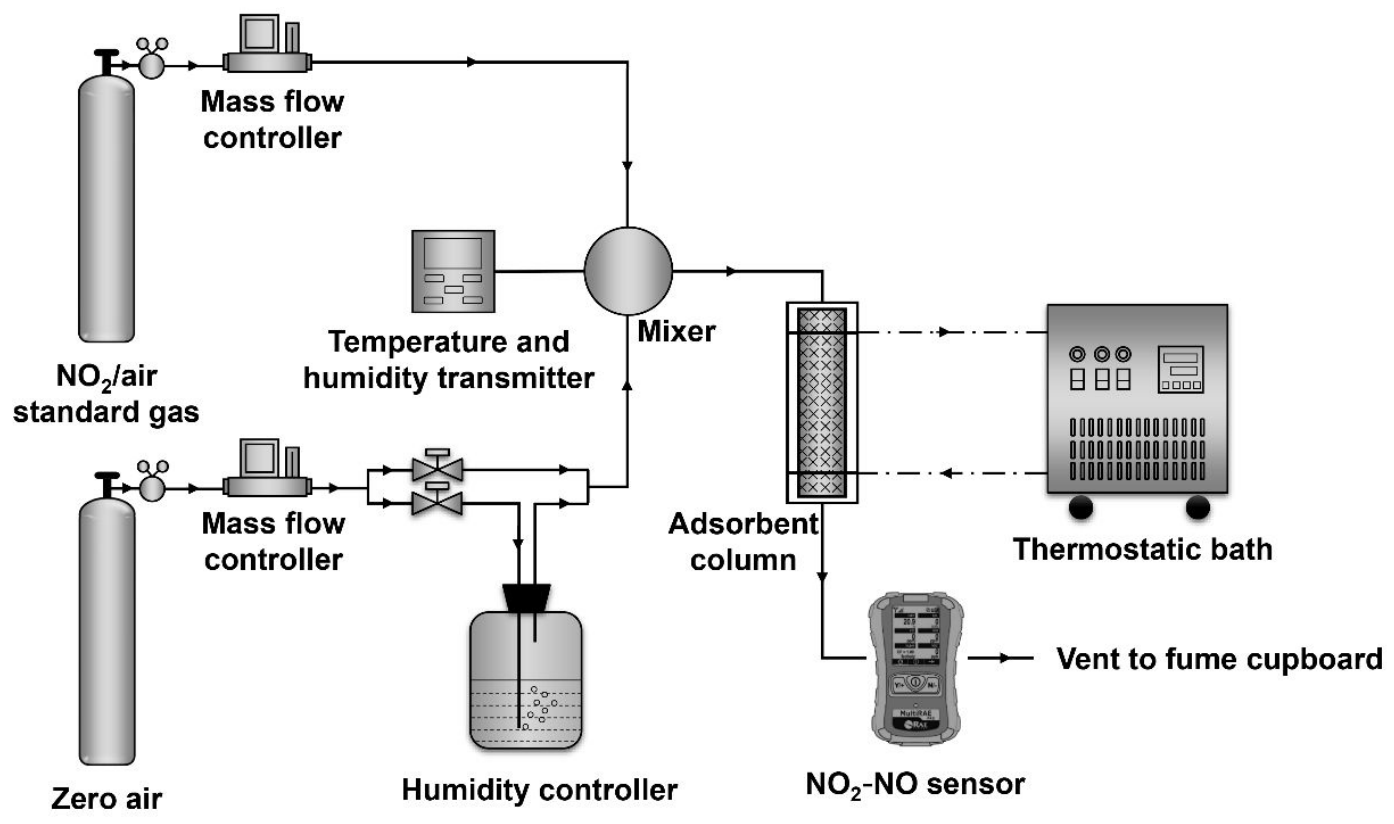

Figure S1. Microbreakthrough test apparatus for powder samples.

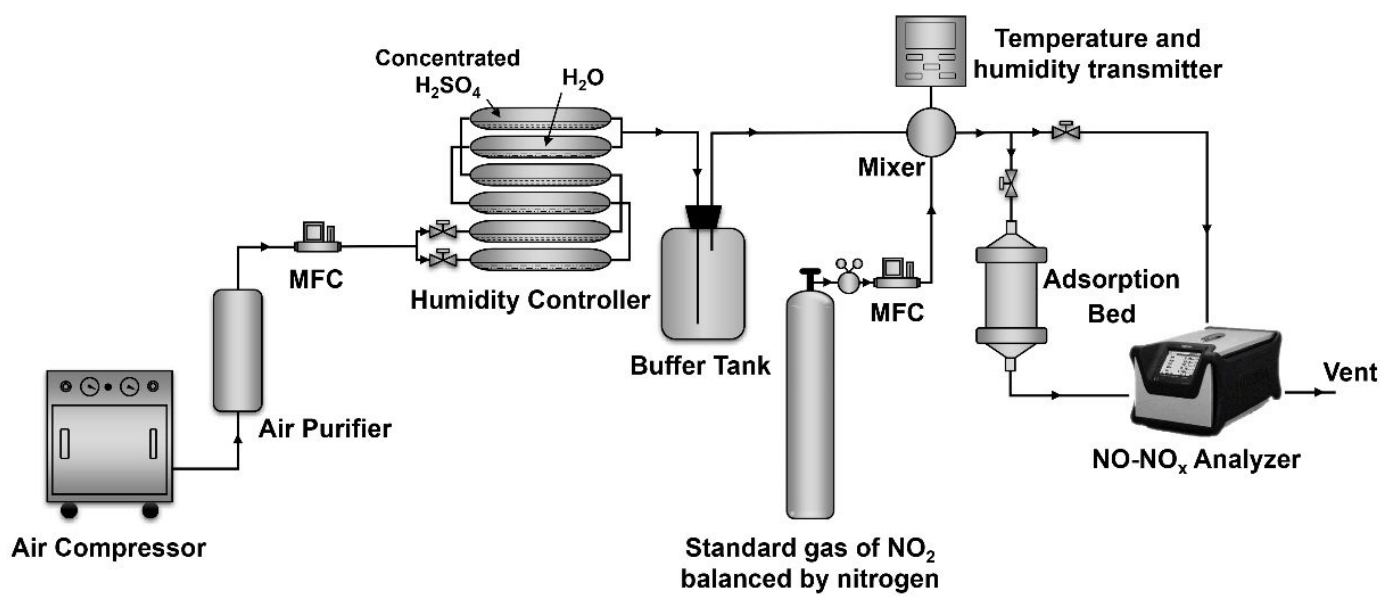

Figure S2. Tube breakthrough system for granule samples. 
Table S1. Microbreakthrough and breakthrough parameters

\begin{tabular}{ccc}
\hline Parameter & Microbreakthrough system & Tube system \\
temperature & $298 \mathrm{~K}$ & $298 \mathrm{~K}$ \\
RH & $0 \%(233 \mathrm{~K} \mathrm{dew}$ point $)$ and $80 \%$ & $15 \%, 50 \%$, and $90 \%$ \\
adsorbent mass & $\sim 20 \mathrm{mg}$ & $\sim 1 \mathrm{~g}$ for precipitates and \\
& & \\
adsorbent bed size & & \\
flow rate & $20 \mathrm{~mL} / \mathrm{min}$ & $\Phi \mathrm{mm}$ for xerogels \\
& $250 \mathrm{ppm}$ & $210 \mathrm{~mL} / \mathrm{min}$ \\
challenge concentration & & $200 \mathrm{ppm}$
\end{tabular}

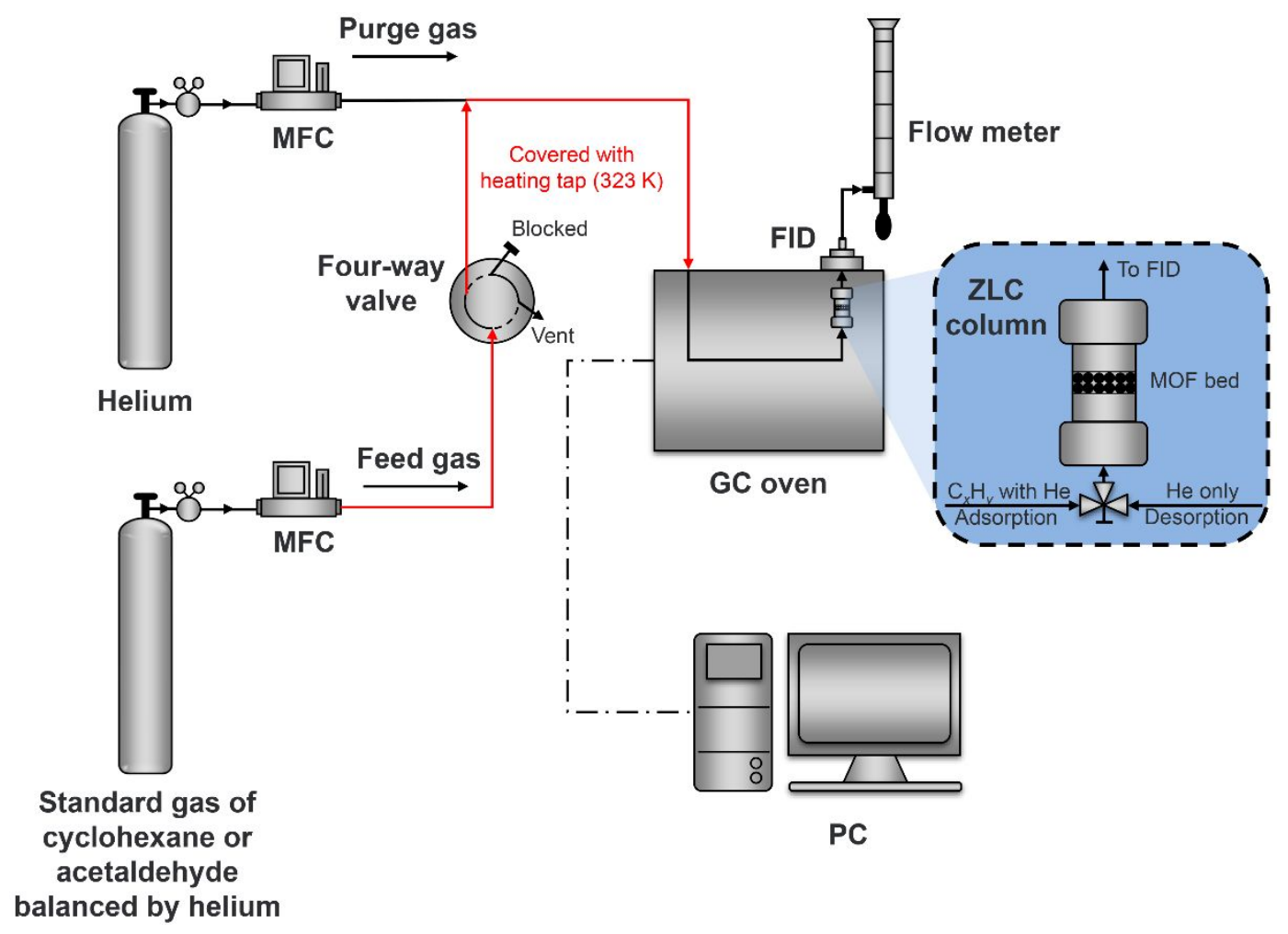

Figure S3. ZLC measurement apparatus. 


\section{S2. Characterization results for $\mathrm{Zr}$-MOF samples.}

Table S2. Compositions derived from ${ }^{1} \mathrm{H}$ NMR analysis of the digested samples

\begin{tabular}{|c|c|c|c|}
\hline Sample & $\begin{array}{c}\text { Peak ratio } \\
\text { (BTC:HCOO: } \mathrm{NH}_{2} \text { IPA) }\end{array}$ & $\begin{array}{c}\mathrm{NH}_{2} \mathrm{IPA} \text { per } \mathrm{Zr}_{6} \\
\text { node }\end{array}$ & Chemical formula ${ }^{a}$ \\
\hline MOF-808 & $1: 0.74$ & NA & $\mathrm{Zr}_{6} \mathrm{O}_{4}(\mathrm{OH})_{4}(\mathrm{BTC})_{2}(\mathrm{HCOO})_{4.44}(\mathrm{OH})_{1.56}$ \\
\hline MOF-808- $\mathrm{NH}_{2}^{b}$ & $1: 0.19: 0.38$ & 2.28 & $\mathrm{Zr}_{6} \mathrm{O}_{4}(\mathrm{OH})_{4}(\mathrm{BTC})_{2}(\mathrm{HCOO})_{1.14}\left(\mathrm{NH}_{2} \mathrm{IPA}\right)_{2.28}(\mathrm{OH})_{0.3}$ \\
\hline G808 & $1: 0.20$ & NA & $\mathrm{Zr}_{6} \mathrm{O}_{4}(\mathrm{OH})_{4}(\mathrm{BTC})_{2}(\mathrm{HCOO})_{1.20}(\mathrm{OH})_{4.80}$ \\
\hline $\mathrm{G} 808-\mathrm{NH}_{2}-5$ & 1:0.10:0.04 & 0.24 & $\mathrm{Zr}_{6} \mathrm{O}_{4}(\mathrm{OH})_{4}(\mathrm{BTC})_{2}(\mathrm{HCOO})_{0.60}\left(\mathrm{NH}_{2} \mathrm{IPA}\right)_{0.24}(\mathrm{OH})_{4.92}$ \\
\hline $\mathrm{G} 808-\mathrm{NH}_{2}-10$ & $1: 0.16: 0.04$ & 0.24 & $\mathrm{Zr}_{6} \mathrm{O}_{4}(\mathrm{OH})_{4}(\mathrm{BTC})_{2}(\mathrm{HCOO})_{0.96}\left(\mathrm{NH}_{2} \mathrm{IPA}\right)_{0.24}(\mathrm{OH})_{4.56}$ \\
\hline $\mathrm{G} 808-\mathrm{NH}_{2}-25$ & $1: 0.17: 0.06$ & 0.36 & $\mathrm{Zr}_{6} \mathrm{O}_{4}(\mathrm{OH})_{4}(\mathrm{BTC})_{2}(\mathrm{HCOO})_{1.02}\left(\mathrm{NH}_{2} \mathrm{IPA}\right)_{0.36}(\mathrm{OH})_{4.26}$ \\
\hline $\mathrm{G} 808-\mathrm{NH}_{2}-50$ & $1: 0.17: 0.11$ & 0.66 & $\mathrm{Zr}_{6} \mathrm{O}_{4}(\mathrm{OH})_{4}(\mathrm{BTC})_{2}(\mathrm{HCOO})_{1.02}\left(\mathrm{NH}_{2} \mathrm{IPA}\right)_{0.66}(\mathrm{OH})_{3.66}$ \\
\hline $\mathrm{G} 808-\mathrm{NH}_{2}-100$ & 1:0.18:0.13 & 0.78 & $\mathrm{Zr}_{6} \mathrm{O}_{4}(\mathrm{OH})_{4}(\mathrm{BTC})_{2}(\mathrm{HCOO})_{1.08}\left(\mathrm{NH}_{2} \mathrm{IPA}\right)_{0.78}(\mathrm{OH})_{3.36}$ \\
\hline $\mathrm{G} 808-\mathrm{NH}_{2}-150$ & $1: 0.22: 0.15$ & 0.90 & $\mathrm{Zr}_{6} \mathrm{O}_{4}(\mathrm{OH})_{4}(\mathrm{BTC})_{2}(\mathrm{HCOO})_{1.32}\left(\mathrm{NH}_{2} \mathrm{IPA}\right)_{0.90}(\mathrm{OH})_{2.88}$ \\
\hline $\mathrm{G} 808-\mathrm{NH}_{2}-300$ & $1: 0.23: 0.22$ & 1.32 & $\mathrm{Zr}_{6} \mathrm{O}_{4}(\mathrm{OH})_{4}(\mathrm{BTC})_{2}(\mathrm{HCOO})_{1.38}\left(\mathrm{NH}_{2} \mathrm{IPA}\right)_{1.32}(\mathrm{OH})_{1.98}$ \\
\hline
\end{tabular}

${ }^{a}$ In consideration of charge-balancing, a part of formate ligands were supposed to be replaced by equal hydroxyl

ligands during the heat treatment in vacuum. ${ }^{b}$ Data from our earlier work. ${ }^{1}$

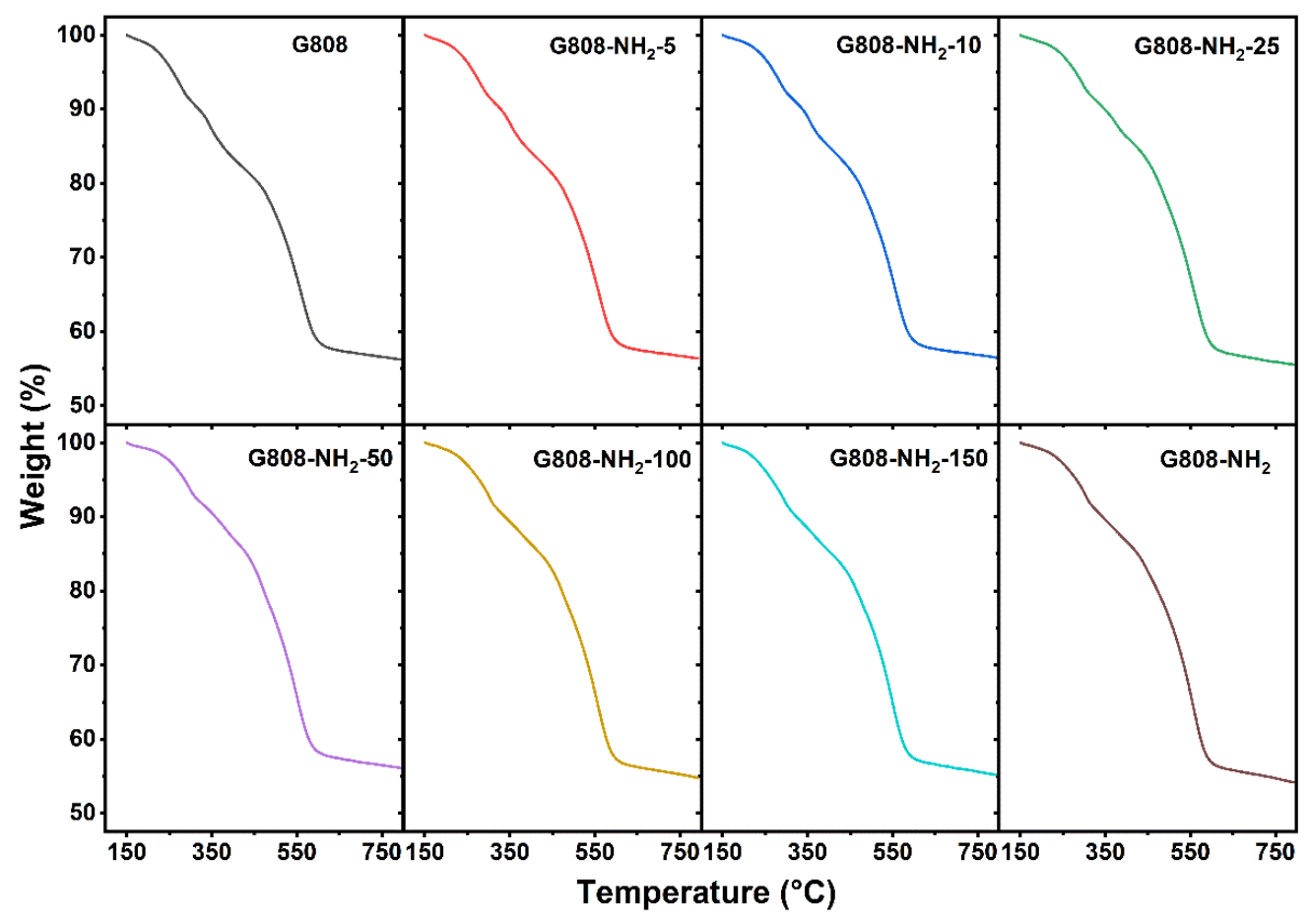

Figure S4. TG curves of G808 and G808- $\mathrm{NH}_{2}(-X)$ samples. 
Table S3. Texture properties of Zr-MOF microcrystalline precipitates and nanocrystalline xerogels

\begin{tabular}{|c|c|c|c|c|c|}
\hline Sample & $\begin{array}{c}S_{\mathrm{BET}} \\
\left(\mathrm{m}^{2} / \mathrm{g}\right)\end{array}$ & $\begin{array}{c}V_{\text {micro }} \\
\left(\mathrm{cm}^{3} / \mathrm{g}\right)\end{array}$ & $\begin{array}{c}V_{\text {meso }} \\
\left(\mathrm{cm}^{3} / \mathrm{g}\right)\end{array}$ & $\begin{array}{c}V_{\text {total }} \\
\left(\mathrm{cm}^{3} / \mathrm{g}\right)\end{array}$ & $\begin{array}{c}V_{\text {meso }} / V_{\text {total }} \\
(\%)\end{array}$ \\
\hline MOF-808 & 1822 & 0.52 & 0.21 & 0.73 & 29 \\
\hline G808 & 1110 & 0.39 & 0.71 & 1.10 & 65 \\
\hline MOF-808-NH & 1174 & 0.37 & 0.32 & 0.69 & 46 \\
\hline G808- $\mathrm{NH}_{2}$ & 1037 & 0.35 & 0.62 & 0.97 & 64 \\
\hline $\mathrm{UiO}-66-\mathrm{NH}_{2}$ & 1165 & 0.38 & 0.16 & 0.54 & 30 \\
\hline G66- $\mathrm{NH}_{2}$ & 762 & 0.16 & 1.05 & 1.21 & 87 \\
\hline
\end{tabular}

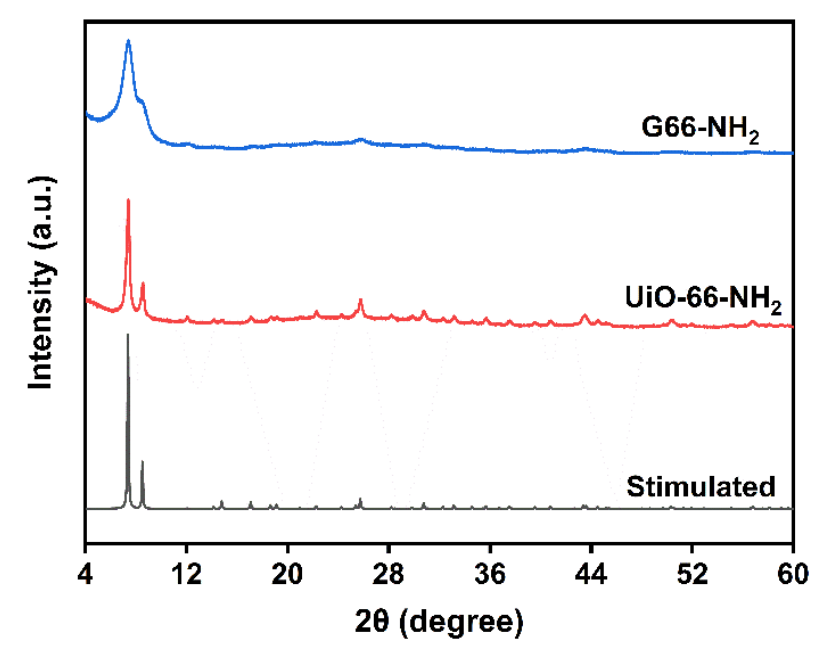

Figure S5. The simulated and experimental PXRD patterns for UiO-66- $\mathrm{NH}_{2}$ and the G66- $\mathrm{NH}_{2}$ xerogel. 


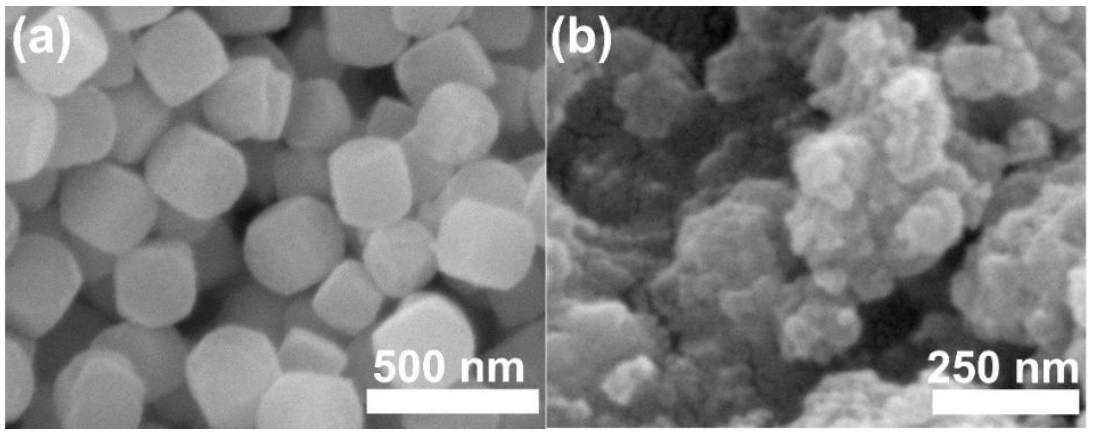

Figure S6. SEM images of (a) $\mathrm{UiO}-66-\mathrm{NH}_{2}$ and (b) the G66- $\mathrm{NH}_{2}$ xerogel.

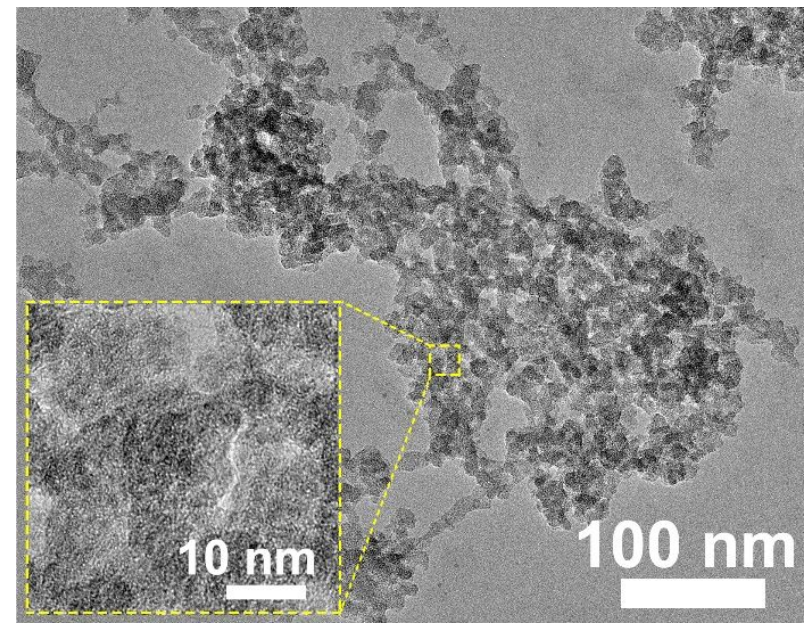

Figure S7. TEM images of the G66- $\mathrm{NH}_{2}$ xerogel.

(a)

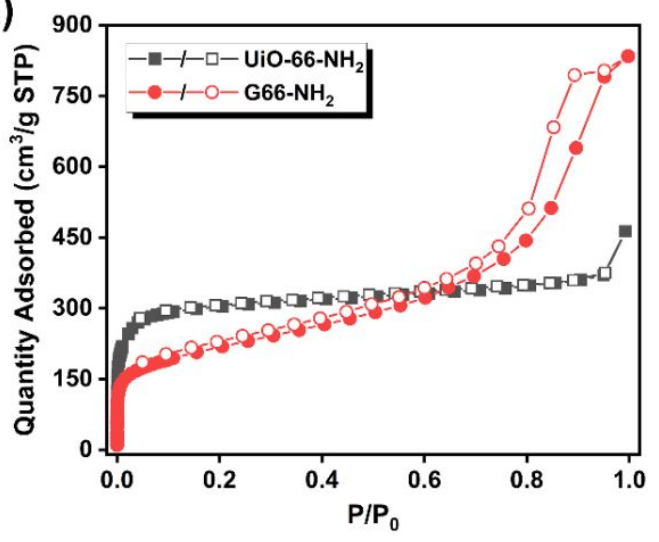

(b)

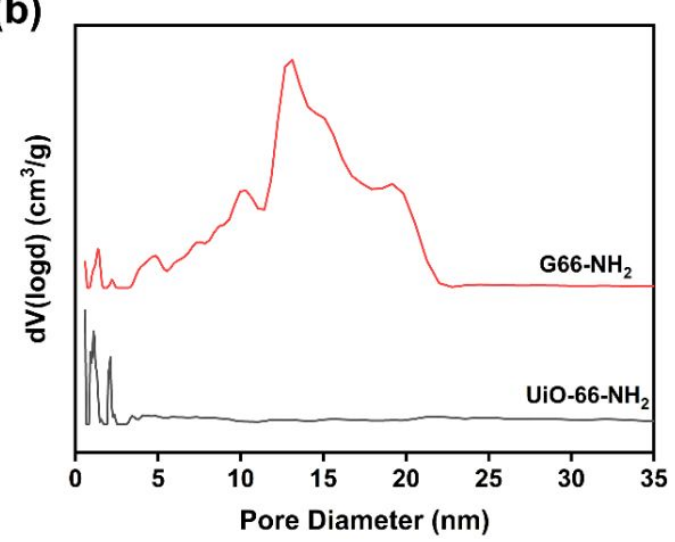

Figure S8. (a) $\mathrm{N}_{2}$ adsorption-desorption isotherms and (b) QSDFT pore size distribution of UiO-66- $\mathrm{NH}_{2}$ and the $\mathrm{G} 66-\mathrm{NH}_{2}$ xerogel. The adsorption and desorption points are represented by solid and void symbols, respectively. 


\section{S3. Structure stability of $\mathrm{Zr}-\mathrm{MOF}$ xerogels after $\mathrm{NO}_{2}$ exposure.}

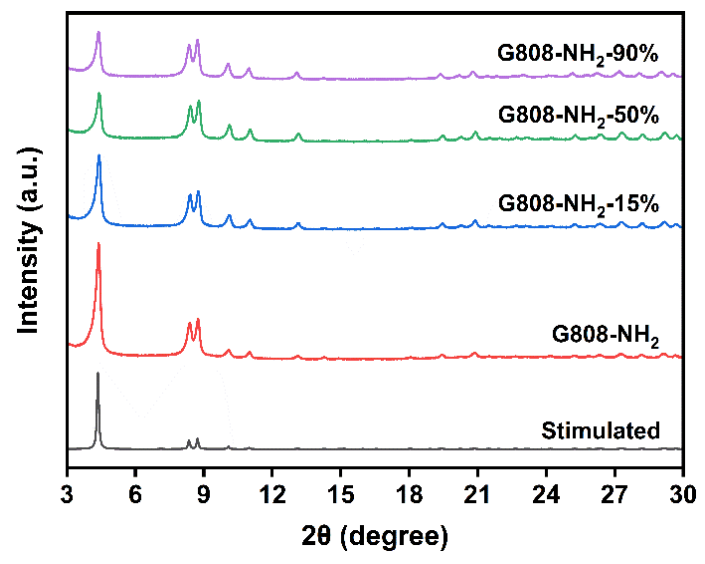

Figure S9. PXRD patterns of the fresh G808- $\mathrm{NH}_{2}$ xerogel and exhausted samples after $\mathrm{NO}_{2}$ exposure at different $\mathrm{RH}$.

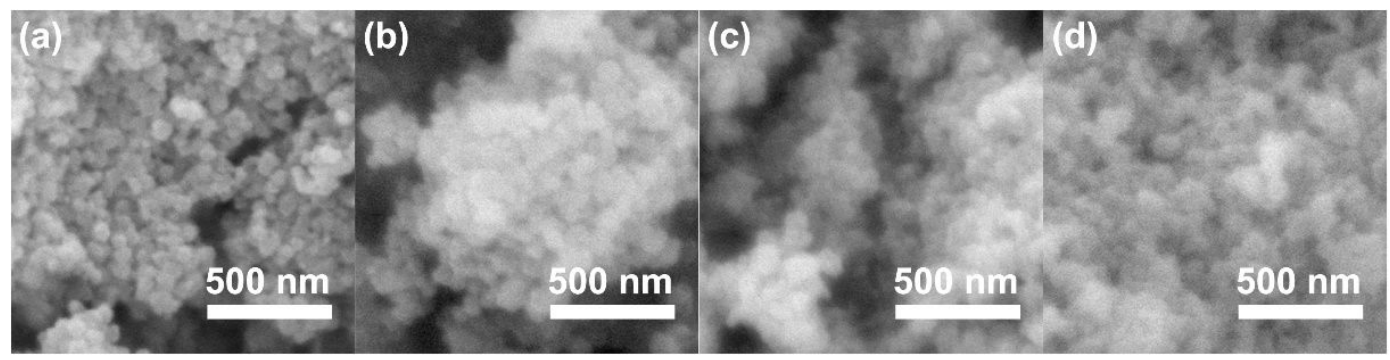

Figure S10. SEM images of (a) G808- $\mathrm{NH}_{2}$, (b) G808- $\mathrm{NH}_{2}-15 \%$, (c) G808- $\mathrm{NH}_{2}-50 \%$,

(d) $\mathrm{G} 808-\mathrm{NH}_{2}-90 \%$.

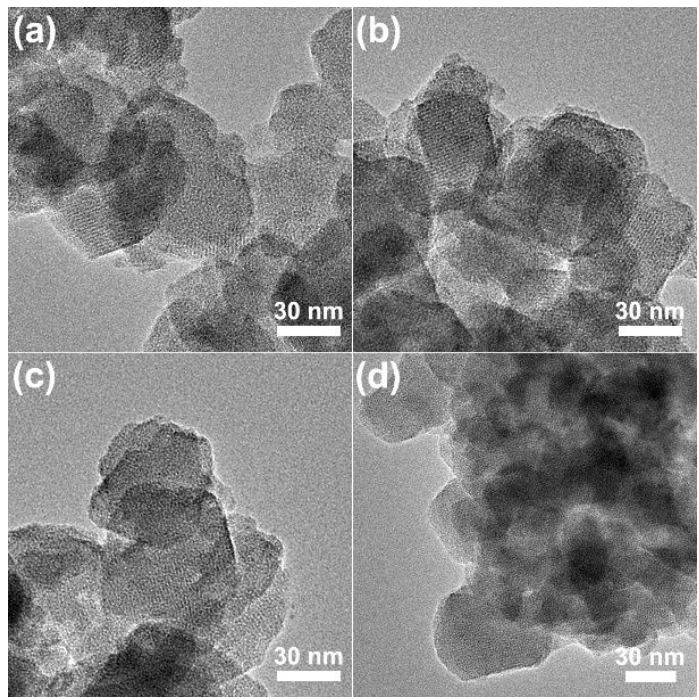


Figure S11. TEM images of (a) G808- $\mathrm{NH}_{2}$, (b) G808- $\mathrm{NH}_{2}-15 \%$, (c) G808- $\mathrm{NH}_{2}-50 \%$, (d) $\mathrm{G} 808-\mathrm{NH}_{2}-90 \%$.
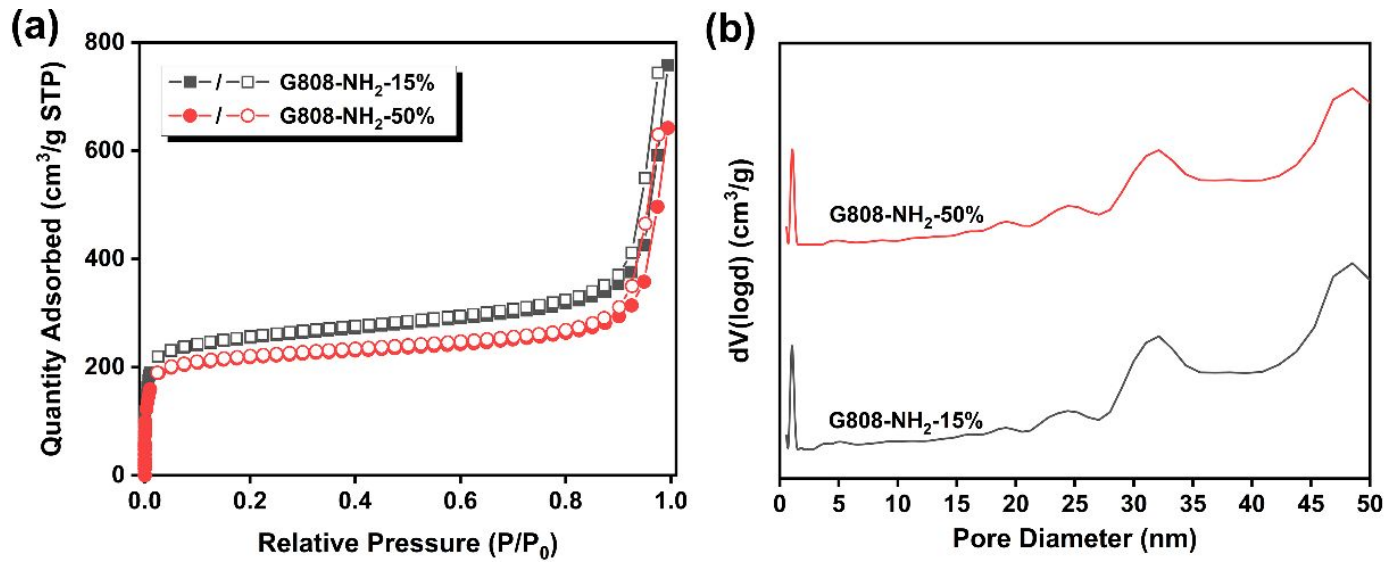

Figure S12. (a) $\mathrm{N}_{2}$ adsorption-desorption isotherms and (b) QSDFT pore size distribution of the exhausted G808- $\mathrm{NH}_{2}$ samples after $\mathrm{NO}_{2}$ exposure at different $\mathrm{RH}$. The adsorption and desorption points are represented by solid and void symbols, respectively. We did not test the sample pre-humidified at $90 \% \mathrm{RH}\left(\mathrm{G} 808-\mathrm{NH}_{2}-90 \%\right)$ due to the interference from capillary-force-driven channel collapse under vacuum.

Table S4. Texture properties of the exhausted G808- $\mathrm{NH}_{2}$ samples after $\mathrm{NO}_{2}$ exposure at different $\mathrm{RH}$

\begin{tabular}{cccccc}
\hline Sample & $S_{\text {BET }}$ & $V_{\text {micro }}$ & $V_{\text {meso }}$ & $V_{\text {total }}$ & $V_{\text {meso }} / V_{\text {total }}$ \\
& $\left(\mathrm{m}^{2} / \mathrm{g}\right)$ & $\left(\mathrm{cm}^{3} / \mathrm{g}\right)$ & $\left(\mathrm{cm}^{3} / \mathrm{g}\right)$ & $\left(\mathrm{cm}^{3} / \mathrm{g}\right)$ & $(\%)$ \\
\hline $\mathrm{G} 808-\mathrm{NH}_{2}-15 \%$ & 978 & 0.33 & 0.63 & 0.96 & 66 \\
$\mathrm{G} 808-\mathrm{NH}_{2}-50 \%$ & 862 & 0.29 & 0.52 & 0.81 & 64 \\
\hline
\end{tabular}




\section{S4. Summary of characterization results for $\mathrm{NO}_{2}$ adsorption mechanism analysis.}

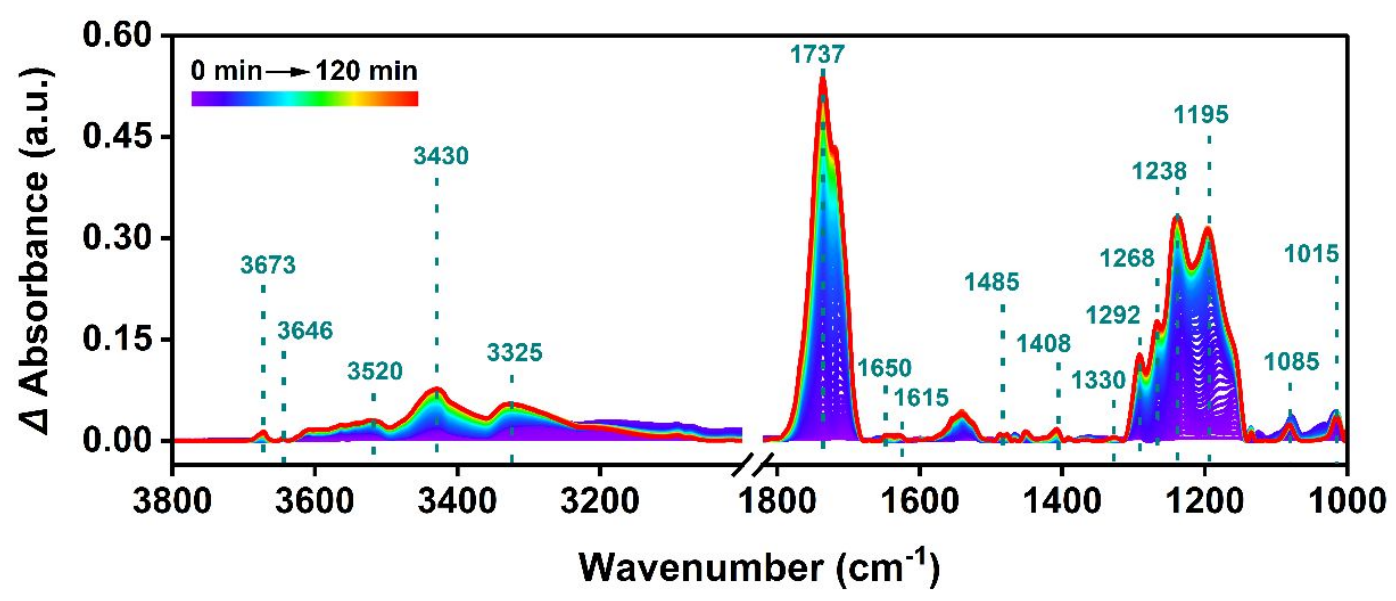

Figure S13. In-situ DRIFTS spectra for the MOF-808- $\mathrm{NH}_{2}$ exposed to dry $\mathrm{NO}_{2}$ as a function of time, where the band positions are annotated.

Table S5. Assignments for the absorbance bands rising after $\mathrm{NO}_{2}$ adsorption in FTIR spectra for the G808- $\mathrm{NH}_{2}$ xerogel

\begin{tabular}{cccc}
\hline Groups/Species & Vibrational mode & Band position $\left(\mathrm{cm}^{-1}\right)$ & Refs. \\
\hline $\mathrm{NH}_{4}{ }^{+} /$hydrogen-bonded $\mathrm{NH}_{3}$ & $\mathrm{~N}-\mathrm{H}$ str. & $3270 \sim 3080$ & 1 \\
$\mathrm{~N}_{2} \mathrm{O}_{4}$ & asym. $\mathrm{NO}_{2}$ str. & 1718 & 2 \\
$-\mathrm{COO}^{-}$ & asym. $\mathrm{COO}^{-}$str. & 1658 & 3 \\
nitramines/nitrosamines & $\mathrm{N}-\mathrm{O}$ str. & 1270 & $4-7$ \\
& $\mathrm{~N}-\mathrm{N}$ str. & 1018 & $4-7$ \\
aromatic nitro compounds & $\mathrm{C}-\mathrm{N}$ str. & 940 & 1 \\
\hline
\end{tabular}


Table S6. Results for the deconvolution of XPS spectra

\begin{tabular}{|c|c|c|c|}
\hline Sample & Groups/Species & Peak position $(\mathrm{eV})$ & Area ratio \\
\hline G808- $\mathrm{NH}_{2}$ & $-\mathrm{NH}_{2}$ & 399.5 & 1.00 \\
\hline \multirow[t]{7}{*}{$\mathrm{G} 808-\mathrm{NH}_{2}-\mathrm{ND}$} & $-\mathrm{NH}_{2}$ & 399.2 & 0.12 \\
\hline & $-\mathrm{NH}_{3}^{+}$ & 400.5 & 1.00 \\
\hline & nitrosamines & 401.9 & 0.13 \\
\hline & nitrites & 403.6 & 0.05 \\
\hline & aromatic nitro compounds & 405.4 & 0.13 \\
\hline & nitramines & 406.5 & 0.35 \\
\hline & nitrates & 407.3 & 0.81 \\
\hline \multirow[t]{5}{*}{ G808--NH $2-\mathrm{NM}$} & $-\mathrm{NH}_{2}$ & 399.9 & 0.20 \\
\hline & $-\mathrm{NH}_{3}^{+}$ & 400.8 & 0.39 \\
\hline & nitrites & 403.2 & 0.06 \\
\hline & aromatic nitro compounds & 405.8 & 0.12 \\
\hline & nitrates & 407.2 & 1.00 \\
\hline
\end{tabular}


Table S7. Assignments of the absorbance DRIFTS bands observed during dry $\mathrm{NO}_{2}$ adsorption over G808- $\mathrm{NH}_{2}$ and MOF-808- $\mathrm{NH}_{2}$

\begin{tabular}{|c|c|c|c|c|}
\hline \multirow[t]{2}{*}{ Groups/Species } & \multirow[t]{2}{*}{ Vibrational Mode } & \multicolumn{2}{|c|}{ Band Position $\left(\mathrm{cm}^{-1}\right)$} & \multirow[t]{2}{*}{ Refs. } \\
\hline & & $\mathrm{G} 808-\mathrm{NH}_{2}$ & MOF-808-NH $\mathrm{NH}_{2}$ & \\
\hline \multirow{3}{*}{$-\mathrm{OH}$} & $\mathrm{O}-\mathrm{H}$ str. & 3673,3636 & 3673,3646 & 2,8 \\
\hline & & 3583,3512 & 3430,3325 & \\
\hline & & 3430,3353 & & \\
\hline $\mathrm{N}_{2} \mathrm{O}_{4}$ & asym. $\mathrm{NO}_{2}$ str. & 1737 & 1737 & $9-11$ \\
\hline HONO & asym. $\mathrm{NO}_{2}$ str. & 1680 & masked & $9-11$ \\
\hline adsorbed $\mathrm{NO}_{2}$ & asym. $\mathrm{NO}_{2}$ str. & 1650 & 1650 & $9-11$ \\
\hline $\mathrm{H}_{2} \mathrm{O}$ & $\mathrm{H}_{2} \mathrm{O}$ def. & 1650 & 1650 & 2 \\
\hline \multirow[t]{2}{*}{ nitramines } & asym. $\mathrm{NO}_{2}$ str. & 1610 & 1615 & 4,12 \\
\hline & $\mathrm{N}-\mathrm{N}$ str. & 1095 & 1085 & \\
\hline \multirow[t]{2}{*}{ nitrosamines } & $\mathrm{N}=\mathrm{O}$ str. & 1485 & 1485 & 4,13 \\
\hline & $\mathrm{N}-\mathrm{N}$ str. & 1095 & 1085 & \\
\hline free nitrates & $v_{3}$ & 1390 & 1408 & 9,10 \\
\hline aromatic nitro & sym. $\mathrm{NO}_{2}$ str. & 1333 & 1330 & 11 \\
\hline \multicolumn{5}{|l|}{ compounds } \\
\hline nonodentate nitrates & split $v_{3}$ & 1292 & 1292 & 9,10 \\
\hline
\end{tabular}


$v_{1}$

bidentate nitrates

bridging nitrates

bridging nitrites split $v_{3}$

$v_{1}$

split $v_{3}$

$v_{1}$

$v_{3}$
1013

1269

1013

1245

1013

1195
1015

1268

9,10

1015

1238

9,10

1015

1195

\section{Quantitative analysis of EXAFS data}

XAFS data process and analysis were completed employing Athena and Artemis software of IFEFFIT data processing package. ${ }^{14}$ Quantitative analysis of EXAFS data was conducted via fitting theoretical FEFF6 signals to the experimental data in R-space. The fitting model was established based on a typical local structure of MOF-808, and scattering contributions from three different types of $\mathrm{Zr}-\mathrm{O}$ as well as the nearest $\mathrm{Zr} \cdots \mathrm{Zr}$ and $\mathrm{Zr} \cdots \mathrm{C}$ single scatter (SS) paths were incorporated. ${ }^{15,16}$ The first shell scattering peak from Zr atom in the G808- $\mathrm{NH}_{2}$ xerogel and MOF-808- $\mathrm{NH}_{2}$ is a convolution of the scattering form nearest oxygens of the $\mathrm{Zr}_{6} \mathrm{O}_{4}(\mathrm{OH})_{4}$ cluster, labeled as $\mathrm{Zr}-\mu_{3} \mathrm{O}$, and from oxygens of BTC/NH $\mathrm{N}_{2} \mathrm{IPA}$ ligands and hydroxyl groups or water, labeled as $\mathrm{Zr}-\mathrm{OOC}$ and $\mathrm{Zr}-\mathrm{OH} / \mathrm{Zr}-\mathrm{OH}_{2}$, respectively. Following $\mathrm{NO}_{2}$ exposure, there exists an additional contribution from oxygens of $\mathrm{NO}_{x}$ ligated to the $\mathrm{Zr}_{6}$ nodes, which is donated as $\mathrm{Zr}-\mathrm{ONO}_{x-1}$. Further scattering leading to the second and third shells are primarily ascribed to the $\mathrm{Zr} \cdots \mathrm{C}$ scattering, as well 
as $\mathrm{Zr} \cdots \mathrm{Zr}$ and outer shell $\mathrm{Zr}-\mathrm{O}$ scattering, respectively. Results of the EXAFS analysis and the best fit values of all fitting parameters are reported in Figure S14 and Table S8 S10. The acceptable amplitude reduction factor $\left(S_{0}^{2}\right)$ and energy shift $\left(\Delta E_{0}\right)$ are acquired, suggesting that the experimental fitting data accord well with the MOF crystallographic model.
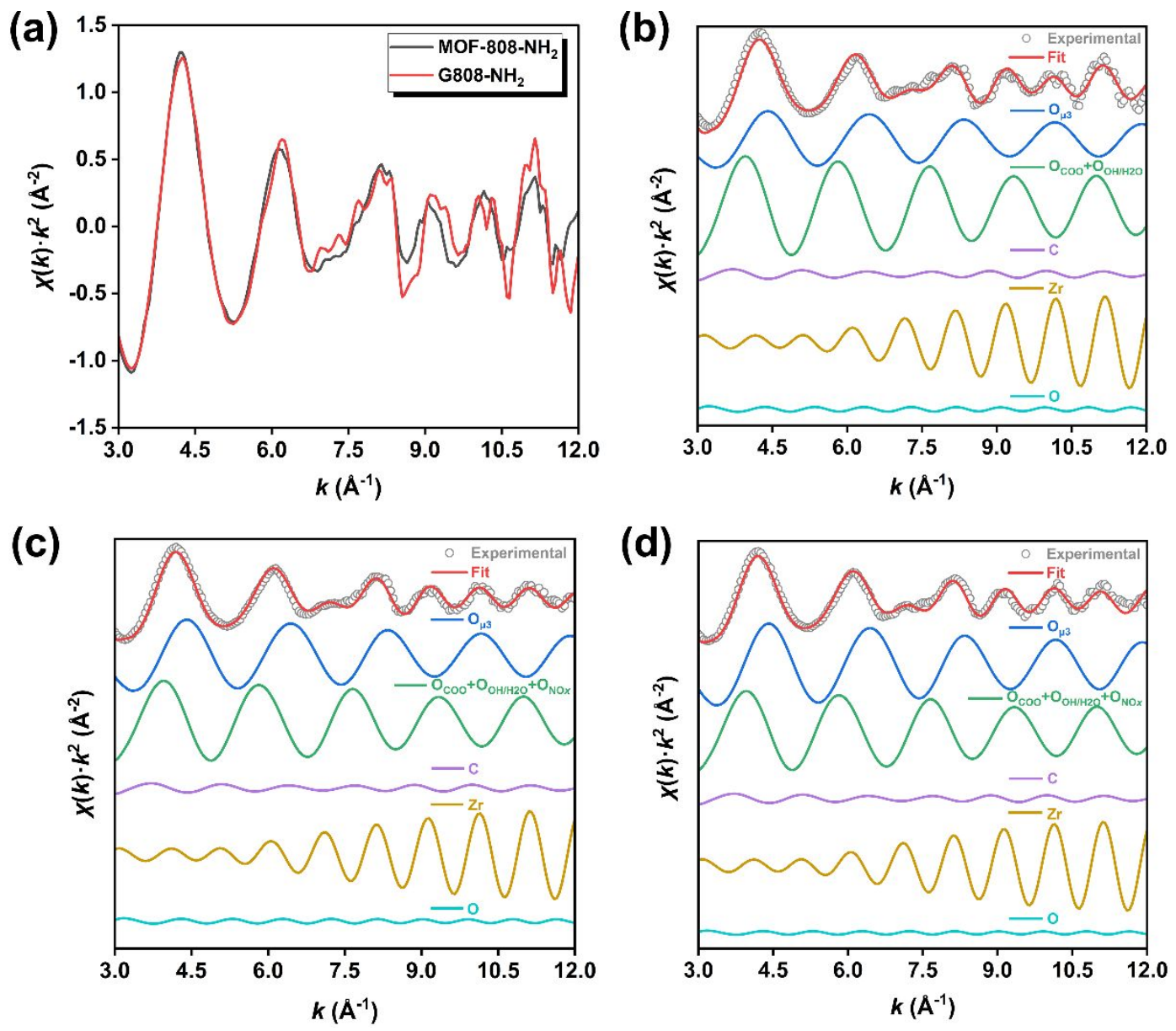

Figure S14. (a) Comparison of the $\mathrm{Zr}$ K-edge EXAFS spectrum for G808- $\mathrm{NH}_{2}$ with that for MOF-808- $\mathrm{NH}_{2}$, and results of the EXAFS analysis of (b) G808- $\mathrm{NH}_{2}$ (c) G808$\mathrm{NH}_{2}-\mathrm{ND}$, and (d) G808- $\mathrm{NH}_{2}-\mathrm{NM}$ samples, shown in $k^{2}$ weighted $k$-space. From top to 
bottom in panel (b): the experimental (scattered circles) and best fit (red line) $k^{2}$-weighted $\chi(k)$ functions; $\mathrm{Zr}-\mu_{3} \mathrm{O}$ SS path (blue line); $\mathrm{Zr}-\mathrm{OOC}, \mathrm{Zr}-\mathrm{OH}$, and $\mathrm{Zr}-\mathrm{OH}_{2} \mathrm{SS}$ paths (green line); $\mathrm{Zr} \cdots \mathrm{C}$ SS path (purple line); $\mathrm{Zr} \cdots \mathrm{Zr}$ SS path (khaki line); $\mathrm{Zr}-\mathrm{O}$ SS path (cyan line). From top to bottom in panel (c) and (d): the experimental (scattered black circles) and best fit (red line) $k^{2}$-weighted $\chi(k)$ functions; $\mathrm{Zr}-\mu_{3} \mathrm{O}$ SS path (blue line); $\mathrm{Zr}-\mathrm{OOC}, \mathrm{Zr}-\mathrm{OH}, \mathrm{Zr}-$ $\mathrm{OH}_{2}$, and $\mathrm{Zr}-\mathrm{ONO}_{x-1} \mathrm{SS}$ paths (green line); $\mathrm{Zr} \cdots \mathrm{C}$ SS path (purple line); $\mathrm{Zr} \cdots \mathrm{Zr}$ SS path (khaki line); Zr-O SS path (cyan line).

Table S8. Summary of EXAFS fitting parameters ${ }^{a}$ for G808- $\mathrm{NH}_{2}$

\begin{tabular}{llll}
\hline $\mathrm{Path}^{b}$ & $N$ & $R(\AA)$ & $\sigma^{2 c}\left(\AA^{2}\right)$ \\
\hline $\mathrm{Zr}-\mu_{3} \mathrm{O}$ & 3.2 & $2.07 \pm 0.02$ & $0.003 \pm 0.001$ \\
$\mathrm{Zr}-\mathrm{OOC} / \mathrm{Zr}-\mathrm{OH} / \mathrm{Zr}-\mathrm{OH}_{2}$ & 6.8 & $2.24 \pm 0.01$ & $0.003 \pm 0.001$ \\
$\mathrm{Zr} \cdots \mathrm{C}$ & 2 & $3.10 \pm 0.04$ & $0.003 \pm 0.005$ \\
$\mathrm{Zr} \cdots \mathrm{Zr}$ & 4 & $3.53 \pm 0.01$ & $0.006 \pm 0.001$ \\
$\mathrm{Zr}-\mathrm{O}$ & 2.0 & $3.92 \pm 0.05$ & $0.003 \pm 0.001$ \\
\hline
\end{tabular}

${ }^{a} S_{0}{ }^{2}$ and $\Delta E_{0}$ were refined as global fit parameters, returning a value of $0.8 \pm 0.1$ and $(2 \pm 1) \mathrm{eV}$, respectively. Data ranges: $3 \leq k \leq 11.5 \AA^{-1}, 1.1 \leq \mathrm{R} \leq 4.1 \AA$. The number of variables is 12 , out of a total of 16 independent data points. R-factor for this fit is $1.1 \% .{ }^{b}$ The distances for all of the paths are from a typical local structure of the MOF-808 second building unit (SBU). ${ }^{c}$ The Debye-Waller factors were constrained to be the same for each type of bond to reduce the number of variables. 
Table S9. Summary of EXAFS fitting parameters ${ }^{a}$ for G808- $\mathrm{NH}_{2}-\mathrm{ND}$

\begin{tabular}{llll}
\hline $\mathrm{Path}^{b}$ & $N$ & $R(\AA)$ & $\sigma^{2 c}\left(\AA^{2}\right)$ \\
\hline $\mathrm{Zr}-\mu_{3} \mathrm{O}$ & 4.2 & $2.12 \pm 0.01$ & $0.004 \pm 0.002$ \\
$\mathrm{Zr}-\mathrm{OOC} / \mathrm{Zr}-\mathrm{OH} / \mathrm{Zr}-\mathrm{OH}_{2} / \mathrm{ZrONO}_{x-1}$ & 5.8 & $2.26 \pm 0.01$ & $0.004 \pm 0.002$ \\
$\mathrm{Zr} \cdots \mathrm{C}$ & 2 & $2.93 \pm 0.20$ & $0.032 \pm 0.041$ \\
$\mathrm{Zr} \cdots \mathrm{Zr}$ & 4 & $3.53 \pm 0.01$ & $0.005 \pm 0.001$ \\
$\mathrm{Zr}-\mathrm{O}$ & & & \\
\hline
\end{tabular}

${ }^{a} S_{0}^{2}$ and $\Delta E_{0}$ were refined as global fit parameters, returning a value of $0.9 \pm 0.1$ and $(1 \pm 1) \mathrm{eV}$, respectively. Data ranges: $3 \leq k \leq 11.5 \AA^{-1}, 1.1 \leq \mathrm{R} \leq 4.1 \AA$. The number of variables is 12 , out of a total of 16 independent data points. R-factor for this fit is $0.6 \%{ }^{b}$ The distances for all of the paths are from a typical local structure of the MOF-808 SBU. ${ }^{c}$ The Debye-Waller factors were constrained to be the same for each type of bond to reduce the number of variables.

Table S10. Summary of EXAFS fitting parameters ${ }^{a}$ for $\mathrm{G} 808-\mathrm{NH}_{2}-\mathrm{NM}$

\begin{tabular}{llll}
\hline Path $^{b}$ & $N$ & $R(\AA)$ & $\sigma^{2 c}\left(\AA^{2}\right)$ \\
\hline $\mathrm{Zr}-\mu_{3} \mathrm{O}$ & 4.8 & $2.12 \pm 0.01$ & $0.002 \pm 0.002$ \\
$\mathrm{Zr}-\mathrm{OOC} / \mathrm{Zr}-\mathrm{OH} / \mathrm{Zr}-\mathrm{OH}_{2} / \mathrm{ZrONO}_{x-1}$ & 5.7 & $2.27 \pm 0.01$ & $0.002 \pm 0.002$ \\
$\mathrm{Zr} \cdots \mathrm{C}$ & 2 & $2.98 \pm 0.20$ & $0.028 \pm 0.039$ \\
$\mathrm{Zr} \cdots \mathrm{Zr}$ & 4 & $3.54 \pm 0.01$ & $0.005 \pm 0.001$
\end{tabular}


${ }^{a} S_{0}{ }^{2}$ and $\Delta E_{0}$ were refined as global fit parameters, returning a value of $0.8 \pm 0.1$ and $(2 \pm 1) \mathrm{eV}$, respectively. Data ranges: $3 \leq k \leq 11.5 \AA^{-1}, 1.1 \leq \mathrm{R} \leq 4.1 \AA$. The number of variables is 12 , out of a total of 16 independent data points. R-factor for this fit is $1.0 \%{ }^{b}$ The distances for all of the paths are from a typical local structure of the MOF-808 SBU. ${ }^{c}$ The Debye-Waller factors were constrained to be the same for each type of bond to reduce the number of variables. 


\section{S5. Adsorption kinetics and mass transfer analysis.}

Table S11. Structure, molecular weight, and kinetic diameters of the adsorbates

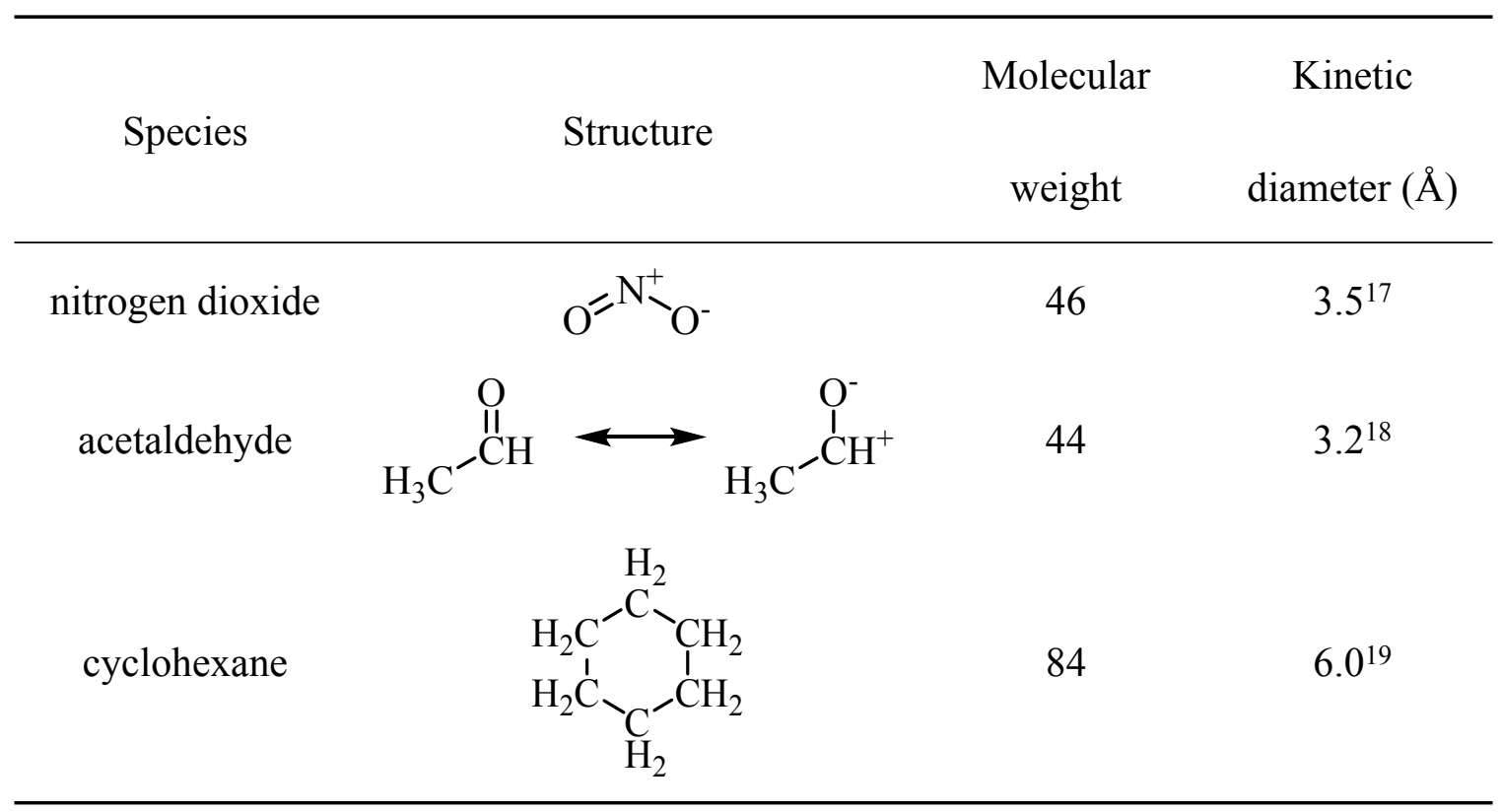

SE and LDF models

In this work, the normalized cyclohexane and acetaldehyde adsorption kinetic profiles corresponding to small pressure increments were described by stretched exponential (SE) and linear driving force (LDF) models. ${ }^{20}$ The SE model is indicated by the following equation $\mathrm{S} 1$ :

$$
\frac{M_{\mathrm{t}}}{M_{\mathrm{e}}}=1-\mathrm{e}^{-(\mathrm{k} t)^{\beta}} \#(\mathrm{~S} 1)
$$

where $M_{\mathrm{t}}$ is the uptake at time $t, M_{\mathrm{e}}$ is the equilibrium uptake, $\mathrm{k}$ is the adsorption rate constant, $\beta$ is the exponent.

The LDF model can be seen as a special nested case of the SE model when $\beta=1$, and 
is given by the equation $\mathrm{S} 2$ :

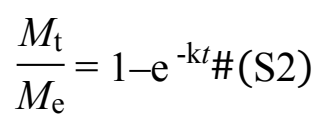

Table S12. Results of exponential fitting with the LDF model for the cyclohexane adsorption kinetics

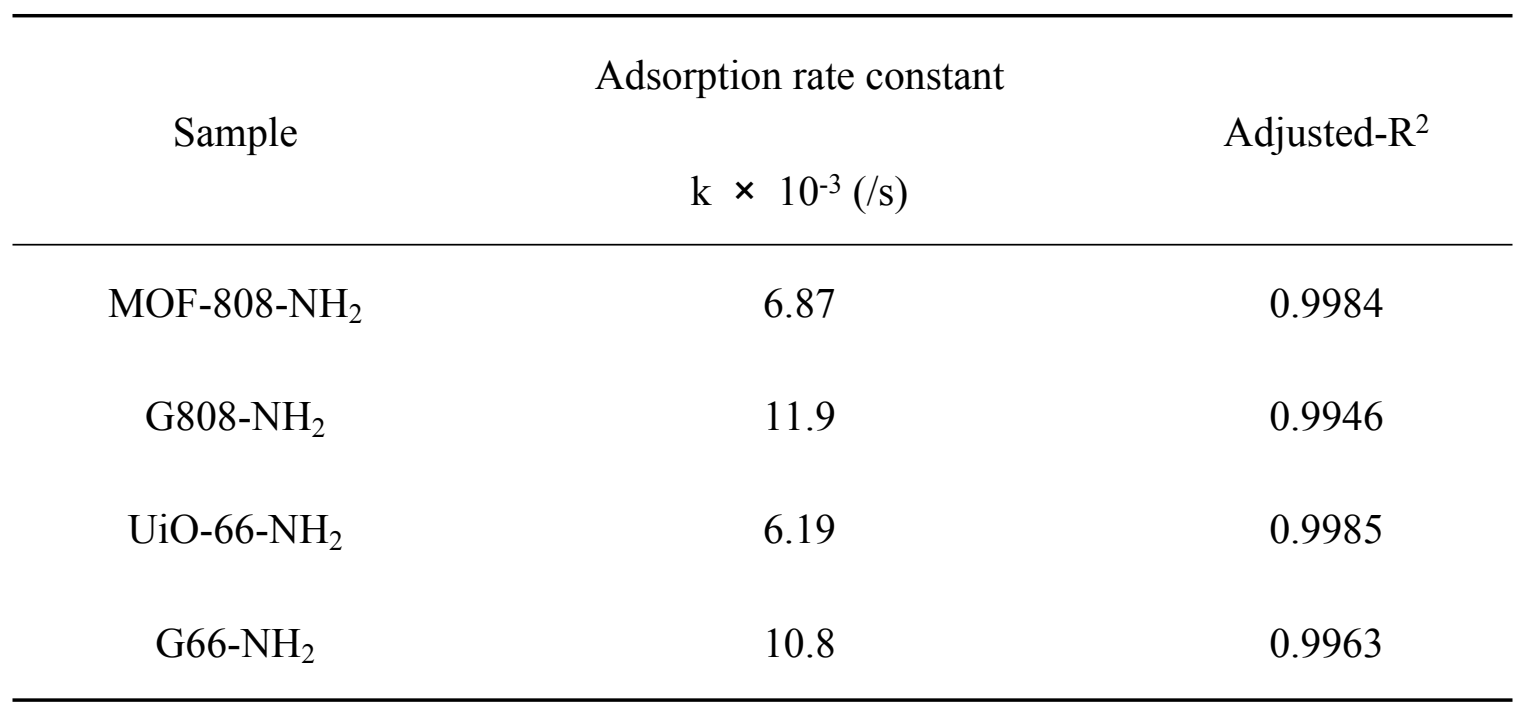

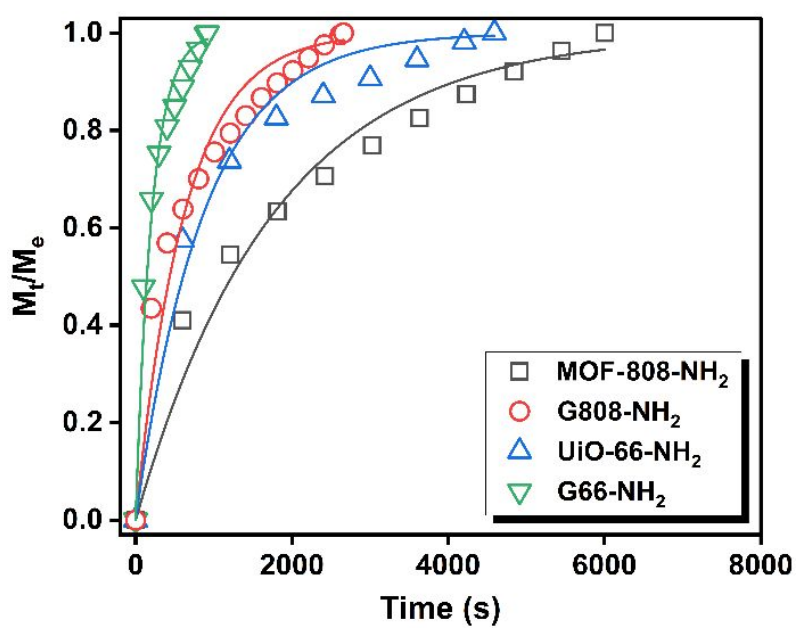

Figure S15. Adsorption kinetic profiles of acetaldehyde at $0.5 \mathrm{mbar}$ and 293K, where symbols and lines represent the experimental data and those calculated by the LDF model, 
respectively.

Table S13. Results of exponential fitting with the SE model for acetaldehyde adsorption kinetics and comparison of the results with the LDF model

\begin{tabular}{|c|c|c|c|c|}
\hline & Adsorption rate constant & Exponent & Adjusted- $\mathrm{R}^{2}$ & Adjusted- $\mathrm{R}^{2}$ \\
\hline & $\mathrm{k} \times 10^{-4}(/ \mathrm{s})$ & $\beta$ & $(\mathrm{SE})$ & (LDF) \\
\hline MOF-808-NH & 6.11 & 0.75 & 0.9802 & 0.9352 \\
\hline $\mathrm{G} 808-\mathrm{NH}_{2}$ & 18.2 & 0.67 & 0.9837 & 0.8944 \\
\hline UiO-66- $\mathrm{NH}_{2}$ & 13.1 & 0.67 & 0.9946 & 0.9074 \\
\hline G66- $\mathrm{NH}_{2}$ & 51.9 & 0.75 & 0.9911 & 0.9502 \\
\hline
\end{tabular}

Theory and measurements for the ZLC technique

The Zero Length Chromatography (ZLC) technique was initially established by Eic and Ruthven in the late 1980s. ${ }^{21}$ From that time on, it had turned into one of the most popular approaches to study the intracrystalline diffusion patterns. ${ }^{22,23}$ The ZLC technique shows the double advantage of removing the interference from extraneous heat and mass transfer resistances for strongly adsorbed species, while minimizing axial dispersion. The inert helium or argon stream containing low concentration of an adsorbate is sent through the ZLC column at high flow rate to guarantee that the adsorbate concentration at the material surface is extremely low (approximate to zero). This is required because it ensures 
that the system is controlled by inner-pore diffusion, which allows one to explore the intracrystalline diffusion behavior of the adsorbate through the adsorbent particles. In the present work, the probe molecules (cyclohexane and acetaldehyde) may become tightly ligated to the Zr-MOF surface. The ZLC method can provide an effective solution for the mass transfer study by virtue of the elimination of the outside forces that could affect the diffusion measurement.

The constitution of a typical ZLC setup has been thoroughly described in the reference, ${ }^{22}$ and a schematic of the ZLC apparatus employed in this study is shown in Figure S3. The core component of the ZLC system is a gas chromatograph (GC) equipped with a flame ionization detector (FID) having high sensitivity on hydrocarbon analytes. The capillary column inside the GC is displaced with a 1/4-inch stainless union that is loaded with an ultrathin layer of Zr-MOF powders $(\sim 5 \mathrm{mg})$. On the basis of the ZLC theory, the adsorbate concentration was modulated at low relative partial pressures $(\sim 0.22$ and 0.08 Torr for cyclohexane and acetaldehyde, respectively) to ensure the measurements were conducted within the linear region of the adsorption isotherms, i.e., within the Henry's law region. The effluent stream was monitored in real time by FID. A ZLC desorption curve was produced based on the concentration of the adsorbate eluted from the Zr-MOF column.

Assuming the adsorption occurring in a very thin layer of MOF spherical crystallites within the Henry's law region, perfect mixing throughout the whole ZLC system, and disregarding the hold-up in the ZLC bed, we can calculate the effective diffusion time 
constant $\left(D_{\text {eff }} / R^{2}\right)$ as well as the characteristic length of the Zr-MOF samples $(L)$ based on the ZLC desorption curves using equation S3:21,24

$$
\frac{C}{C_{0}}=2 L \sum_{n=1}^{\infty} \frac{\exp \left[-\beta_{n}^{2}\left(\frac{D_{\text {eff }}}{R^{2}}\right) t\right]}{\beta_{n}^{2}+L(L-1)} \#(\mathrm{~S} 3)
$$

where $C / C_{0}$ is the relative adsorbate concentration in the effluent, $t$ is time, $R$ is the particle radius, and the eigenvalues $\beta_{\mathrm{n}}$ can be derived from the roots of the auxiliary equations S4 and S5:

$$
\beta_{n} \cot \beta_{n}+L-1=0 \#(\mathrm{~S} 4)
$$

and

$$
L=\frac{1 F R^{2}}{3 K V_{\mathrm{S}} D_{\mathrm{eff}}} \#(\mathrm{~S} 5)
$$

where $F$ is the purge flow rate, $K$ is the Henry's law constant, $V_{s}$ is the adsorbent volume.

On the basis of the aforementioned equations, $D_{\text {eff }} / R^{2}$ and $L$ values can be obtained by fitting equations S3 S5 to the experimental ZLC data using the full range (FR) method and nonlinear least squares fitting. ${ }^{25}$

Moreover, the relationship between the temperature and diffusivity is described by the Arrhenius equation S6:

$$
\mathrm{D}=\mathrm{D}_{0} \exp \left(\frac{-\mathrm{E}_{\mathrm{a}}}{\mathrm{R}_{\mathrm{g}} \mathrm{T}}\right) \#(\mathrm{~S} 6)
$$

Based on the experimental results at four different temperatures $(313,333,353$, and $373 \mathrm{~K}$ ), estimates for the activation energy $E_{\mathrm{a}}$ of intracrystalline diffusion can be obtained 
by equation S7:

$$
E_{\mathrm{a}}=\mathrm{R}_{\mathrm{g}} T^{2}\left(\frac{\partial \ln \frac{D_{\text {eff }}}{R^{2}}}{\partial T}\right) \#(\mathrm{~S} 7)
$$

where $\mathrm{R}_{\mathrm{g}}$ is the ideal gas constant, $E_{\mathrm{a}}$ can be calculated from the slope of the line which is acquired by plotting $\ln \left(D_{\text {eff }} / R^{2}\right)$ versus $1 / T .^{26}$
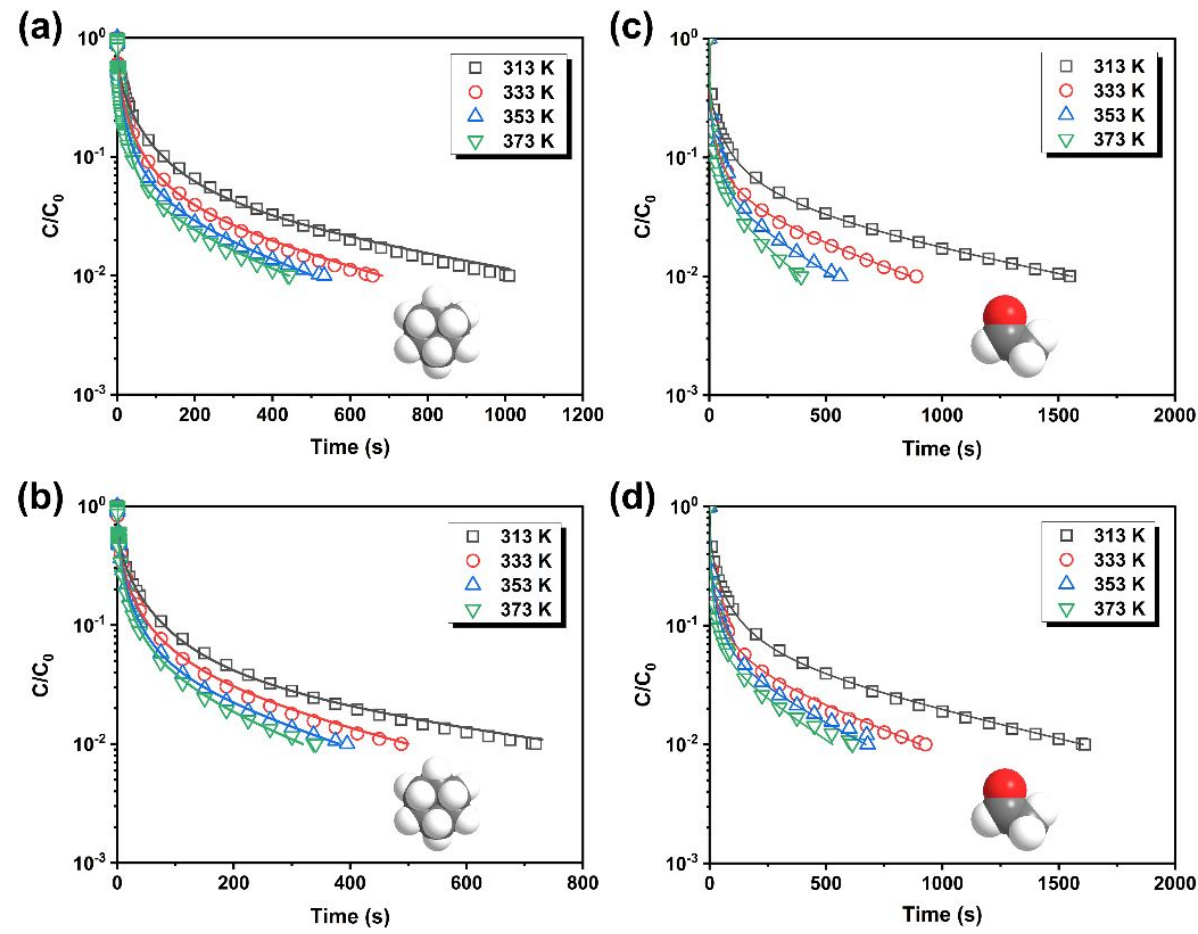

Figure S16. Experimental (symbols) and fitted (lines) ZLC desorption curves for cyclohexane and acetaldehyde in $(\mathrm{a}, \mathrm{c}) \mathrm{UiO}-66-\mathrm{NH}_{2}$ and $(\mathrm{b}, \mathrm{d}) \mathrm{G} 66-\mathrm{NH}_{2}$ at varied temperatures. Insets in (a, b) and (c, d) are space-filling models of cyclohexane and acetaldehyde, respectively, where $\mathrm{C}, \mathrm{O}$, and $\mathrm{H}$ elements are separately represented by grey, red, and white atoms. 
Table S14. Parameters extracted from the ZLC curves for cyclohexane

\begin{tabular}{|c|c|c|c|c|}
\hline Sample & $T(\mathrm{~K})$ & $L$ & $D_{e f f} / R^{2}(/ \mathrm{s})$ & $E_{a}(\mathrm{~kJ} / \mathrm{mol})$ \\
\hline \multirow{5}{*}{ MOF-808-NH ${ }_{2}$} & 313 & 138.73 & $2.17 \times 10^{-4}$ & \multirow{5}{*}{58.0} \\
\hline & 333 & 138.44 & $4.96 \times 10^{-4}$ & \\
\hline & & & & \\
\hline & 353 & 87.44 & $20.0 \times 10^{-4}$ & \\
\hline & 373 & 32.37 & $75.1 \times 10^{-4}$ & \\
\hline \multirow{5}{*}{$\mathrm{G} 808-\mathrm{NH}_{2}$} & 313 & 134.60 & $2.96 \times 10^{-4}$ & \multirow{5}{*}{57.6} \\
\hline & 333 & 134.85 & $6.40 \times 10^{-4}$ & \\
\hline & & & & \\
\hline & 353 & 32.18 & $35.7 \times 10^{-4}$ & \\
\hline & 373 & 25.91 & $92.5 \times 10^{-4}$ & \\
\hline \multirow{5}{*}{ UiO-66-NH ${ }_{2}$} & 313 & 151.12 & $1.25 \times 10^{-4}$ & \multirow{5}{*}{14.1} \\
\hline & 333 & 146.95 & $2.14 \times 10^{-4}$ & \\
\hline & & & & \\
\hline & 353 & 150.69 & $2.62 \times 10^{-4}$ & \\
\hline & 373 & 152.92 & $3.04 \times 10^{-4}$ & \\
\hline \multirow{5}{*}{ G66- $\mathrm{NH}_{2}$} & 313 & 161.24 & $1.65 \times 10^{-4}$ & \multirow{5}{*}{16.5} \\
\hline & 333 & 146.47 & $2.93 \times 10^{-4}$ & \\
\hline & & & & \\
\hline & 353 & 145.95 & $3.84 \times 10^{-4}$ & \\
\hline & 373 & 145.55 & $4.62 \times 10^{-4}$ & \\
\hline
\end{tabular}


Table S15. Parameters extracted from the ZLC curves for acetaldehyde

\begin{tabular}{|c|c|c|c|c|}
\hline Sample & $T(\mathrm{~K})$ & $L$ & $D_{e f f} / R^{2}(/ \mathrm{s})$ & $E_{a}(\mathrm{~kJ} / \mathrm{mol})$ \\
\hline \multirow{5}{*}{ MOF-808- $\mathrm{NH}_{2}$} & 313 & 139.43 & $1.46 \times 10^{-4}$ & \multirow{5}{*}{14.3} \\
\hline & 333 & 146.31 & $1.71 \times 10^{-4}$ & \\
\hline & & & & \\
\hline & 353 & 145.84 & $2.35 \times 10^{-4}$ & \\
\hline & 373 & 145.67 & $3.56 \times 10^{-4}$ & \\
\hline \multirow{4}{*}{$\mathrm{G} 808-\mathrm{NH}_{2}$} & 313 & 162.61 & $1.78 \times 10^{-4}$ & \multirow{4}{*}{19.1} \\
\hline & 333 & 162.25 & $2.58 \times 10^{-4}$ & \\
\hline & 353 & 162.24 & $3.18 \times 10^{-4}$ & \\
\hline & 373 & 162.24 & $6.27 \times 10^{-4}$ & \\
\hline \multirow{4}{*}{ UiO-66-- $\mathrm{NH}_{2}$} & 313 & 194.98 & $0.93 \times 10^{-4}$ & \multirow{4}{*}{19.3} \\
\hline & 333 & 195.39 & $1.67 \times 10^{-4}$ & \\
\hline & 353 & 190.38 & $2.75 \times 10^{-4}$ & \\
\hline & 373 & 148.95 & $2.92 \times 10^{-4}$ & \\
\hline \multirow{5}{*}{ G66-NH ${ }_{2}$} & 313 & 145.92 & $1.09 \times 10^{-4}$ & \multirow{5}{*}{16.7} \\
\hline & 333 & 161.97 & $1.81 \times 10^{-4}$ & \\
\hline & & & & \\
\hline & 353 & 162.26 & $2.44 \times 10^{-4}$ & \\
\hline & 373 & 162.24 & $3.09 \times 10^{-4}$ & \\
\hline
\end{tabular}




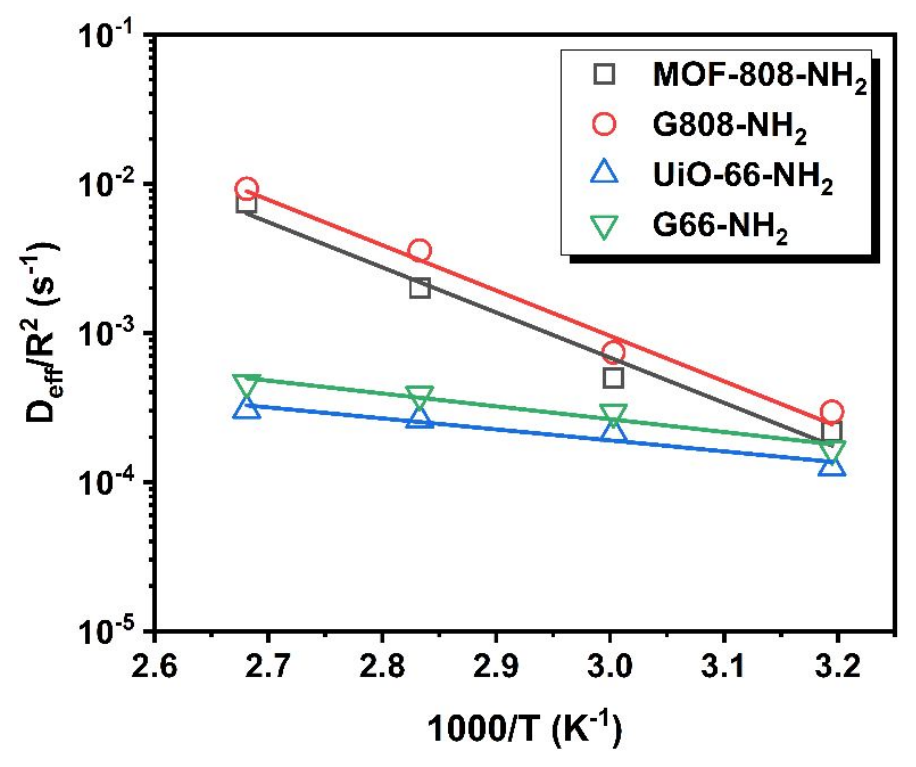

Figure S17. Transport diffusion time constants $\left(D_{\text {eff }} / R^{2}\right)$ for cyclohexane as a function of temperature.

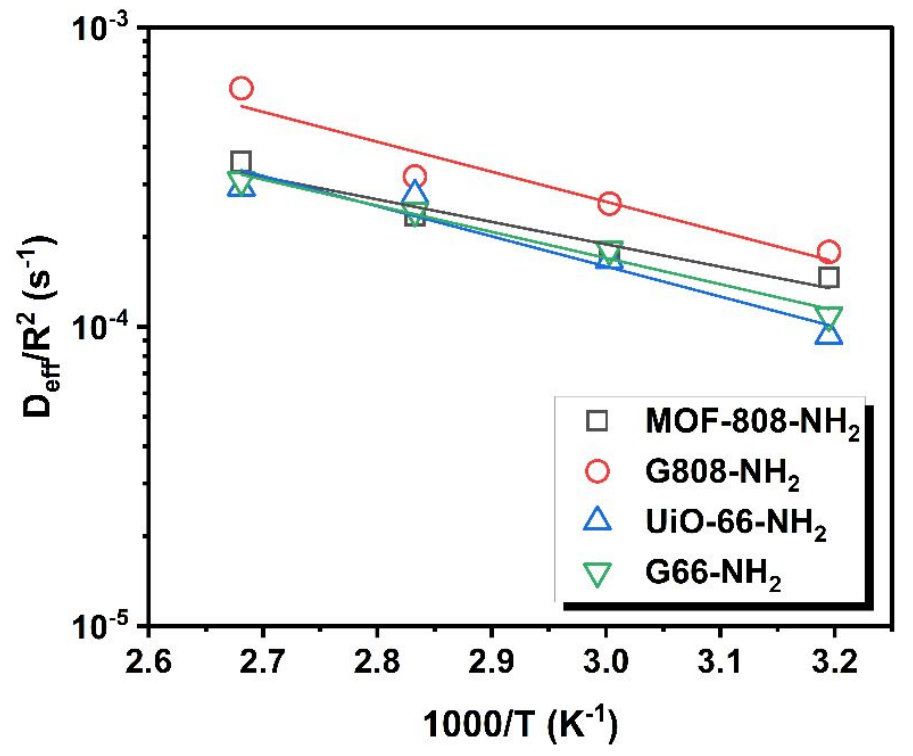

Figure S18. Transport diffusion time constants $\left(D_{\text {eff }} / R^{2}\right)$ for acetaldehyde as a function of temperature. 


\section{References}

(1) Wang, X.; Xu, Z.; Li, L.; Zhao, Y.; Su, R.; Liang, G.; Yang, B.; Miao, Y.; Meng, W.;

Luan, Z.; Li, K.; Xi, H.; Zou, R. $\mathrm{NO}_{2}$ Removal under Ambient Conditions by Nanoporous

Multivariate Zirconium-Based Metal-Organic Framework. ACS Appl. Nano Mater. 2020,

$3(11), 11442-11454$.

(2) Kantcheva, M.; Ciftlikli, E. Z. FTIR Spectroscopic Characterization of $\mathrm{NO}_{x}$ Species Adsorbed on $\mathrm{ZrO}_{2}$ and $\mathrm{ZrO}_{2}-\mathrm{SO}_{4}{ }^{2-}$. J. Phys. Chem. B 2002, 106, 3941-3949.

(3) Pigos, J. M.; Brooks, C. J.; Jacobs, G.; Davis, B. H. Low Temperature Water-Gas

Shift: The Effect of Alkali Doping on the $\mathrm{C}-\mathrm{H}$ Bond of Formate over $\mathrm{Pt} / \mathrm{ZrO}_{2}$ Catalysts. Applied Catalysis A: General 2007, 328, 14-26.

(4) Park, D.; Kim, J.; Lee, Y. M.; Park, J.; Kim, W. J. Polydopamine Hollow Nanoparticle Functionalized with N-Diazeniumdiolates as a Nitric Oxide Delivery Carrier for Antibacterial Therapy. Adv. Healthcare Mater. 2016, 5, 2019-2024.

(5) Deliyanni, E.; Bandosz, T. J. Effect of Carbon Surface Modification with Dimethylamine on Reactive Adsorption of $\mathrm{NO}_{x}$. Langmuir 2011, 27 (5), 1837-1843.

(6) Shi, H.; Supap, T.; Idem, R.; Gelowitz, D.; Campbell, C.; Ball, M. Nitrosamine Formation in Amine-Based $\mathrm{CO}_{2}$ Capture in the Absence of $\mathrm{NO}_{2}$ : Molecular Modeling and Experimental Validation. Environ. Sci. Technol. 2017, 51, 7723-7731.

(7) Ebrahim, A. M.; Levasseur, B.; Bandosz, T. J. Interactions of $\mathrm{NO}_{2}$ with $\mathrm{Zr}$-Based MOF: Effects of the Size of Organic Linkers on $\mathrm{NO}_{2}$ Adsorption at Ambient Conditions. 
Langmuir 2013, 29, 168-174.

(8) McEntee, M.; Peterson, G. W.; Balboa, A.; Iordanov, I.; Balow, R. B.; Pehrsson, P. E. Surface Chemistry of Sulfur Dioxide on $\mathrm{Zr}(\mathrm{OH})_{4}$ Powder: The Role of Water. J. Phys. Chem. C 2019, 123, 17205-17213.

(9) Debeila, M. A.; Coville, N. J.; Scurrell, M. S.; Hearne, G. R. The Effect of Calcination Temperature on the Adsorption of Nitric Oxide on $\mathrm{Au}_{-} \mathrm{TiO}_{2}$ : DRIFTS Studies. Appl. Catal., A 2005, 291, 98-115.

(10) Hadjiivanov, K. I. Identification of Neutral and Charged $\mathrm{N}_{x} \mathrm{O}_{y}$ Surface Species by IR Spectroscopy. Catal. Rev. 2000, 42, 71-144.

(11) Bhattacharyya, S.; Han, R.; Joshi, J. N.; Zhu, G.; Lively, R. P.; Walton, K. S.; Sholl, D. S.; Nair, S. Stability of Zeolitic Imidazolate Frameworks in $\mathrm{NO}_{2}$. J. Phys. Chem. C 2019, 123, 2336-2346.

(12) Tuazon, E. C.; Winer, A. M.; Graham, R. A.; Schmid, J. P.; Pitts, J. N. Fourier Transform Infrared Detection of Nitramines in Irradiated Amine-Nitrogen Oxides $\left(\mathrm{NO}_{x}\right)$ Systems. Environ. Sci. Technol. 1978, 12, 954-958.

(13) Tarte, P. Some Remarks on the Spectra of Nitrites and Nitrosamines. J. Phys. Chem. 1955, 23, 979.

(14) Ravel, B.; Newville, M. ATHENA, ARTEMIS, HEPHAESTUS: Data Analysis for X-Ray Absorption Spectroscopy Using IFEFFIT. J. Synchrotron Rad. 2005, 12 (4), $537-541$. 
C. H.; Senanayake, S. D.; Morris, J. R.; Hill, C. L.; Frenkel, A. I. In Situ Probes of Capture and Decomposition of Chemical Warfare Agent Simulants by Zr-Based Metal Organic Frameworks. J. Am. Chem. Soc. 2017, 139 (2), 599-602. Ji, P.; Solomon, J. B.; Lin, Z.; M. Wilders, A.; Jordan, R. F.; Lin, W. Transformation of Metal-Organic Framework Secondary Building Units into Hexanuclear Zr-Alkyl Catalysts for Ethylene Polymerization. J. Am. Chem. Soc. 2017, 139 (33), 1132511328. Chiari, L.; Zecca, A.; García, G.; Blanco, F.; Brunger, M. J. Low-Energy Positron and Electron Scattering from Nitrogen Dioxide. J. Phys. B: At. Mol. Opt. Phys. 2013, 46 (23), 235202.

$$
\text { Yao, X.; Liu, Y.; Li, T.; Zhang, T.; Li, H.; Wang, W.; Shen, X.; Qian, F.; Yao, Z. }
$$

Adsorption Behavior of Multicomponent Volatile Organic Compounds on a Citric Acid Residue Waste-Based Activated Carbon: Experiment and Molecular Simulation. J. Hazard. Mater. 2020, 392, 122323. Li, C.; Ren, Y.; Gou, J.; Liu, B.; Xi, H. Facile Synthesis of Mesostructured ZSM-5 Zeolite with Enhanced Mass Transport and Catalytic Performances. Appl. Surf. Sci. 2017, $392,785-794$. Fletcher, A. J.; Uygur, Y.; Thomas, K. M. Role of Surface Functional Groups in the Adsorption Kinetics of Water Vapor on Microporous Activated Carbons. J. Phys. Chem. 
C 2007, 111 (23), 8349-8359.

(21) Eic, M.; Ruthven, D. M. A New Experimental Technique for Measurement of Intracrystalline Diffusivity. Zeolites 1988, 8 (1), 40-45.

(22) Brandani, S.; Mangano, E. The Zero Length Column Technique to Measure Adsorption Equilibrium and Kinetics: Lessons Learnt from 30 Years of Experience. Adsorption 2020, 2020, 1-33.

(23) Ruthven, D. M.; Kärger, J.; Brandani, S.; Mangano, E. Sorption Kinetics: Measurement of Surface Resistance. Adsorption 2020, 27 (2021), 787-799.

(24) Hufton, J. R.; Ruthven, D. M. Diffusion of Light Alkanes in Silicalite Studied by the Zero Length Column Method. Ind. Eng. Chem. Res. 1993, 32 (10), 2379-2386.

(25) Han, M.; Yin, X.; Jin, Y.; Chen, S. Diffusion of Aromatic Hydrocarbon in ZSM5 Studied by the Improved Zero Length Column Method. Ind. Eng. Chem. Res. 1999, 38 (8), 3172-3175.

(26) Song, A.; Ma, J.; Xu, D.; Li, R. Adsorption and Diffusion of Xylene Isomers on Mesoporous Beta Zeolite. Catalysts 2015, 5 (4), 2098-2114. 